\title{
Glycosylated haemoglobin concentrations in mothers of large babies
}

\author{
J M STEEL, P THOMSON, F JOHNSTONE, A F SMITH
}

\begin{abstract}
Mothers who have big babies may have had abnormal glucose tolerance during pregnancy. Glycosylated haemoglobin $\left(\mathrm{HbA}_{1}\right)$ concentrations were measured on the first or second day after delivery in 50 women who had had babies weighing over the 95th centile for gestational age and in 50 women who had had normal-sized babies (controls). Nine of the mothers of big babies but only one of the controls had an $H_{b A_{1}}$ concentration above the normal range. All the women had normal glucose tolerance and $\mathrm{HbA}_{1}$ concentrations six weeks after delivery.

Measuring $\mathrm{HbA}_{1}$ concentration in the first two days after delivery in mothers of large babies may identify gestational diabetics.
\end{abstract}

\section{Introduction}

The delivery of a large baby may indicate that the mother had abnormal glucose tolerance during pregnancy. In the gestational diabetic, by definition, glucose tolerance returns to normal after delivery. It is therefore not possible to confirm the diagnosis retrospectively by conventional measures of carbohydrate metabolism.

\begin{abstract}
Method
Glycosylated haemoglobin was measured by a modification of the method of Kynoch and Lehmann ${ }^{2} 3$ on the first or second day after delivery in 50 mothers who had had babies weighing over the 95th centile for gestational age. ${ }^{4}$ Glycosylated haemoglobin was also measured at the same time in a control group of 50 mothers who had had a baby weighing between the 10th and 90th centile for gestational age. The normal range for non-diabetic adults for this method in our laboratory is $5 \cdot 6-8.0 \%$ (mean 6.8 , SD 0.6 ). Women with insulindependent diabetes and those known to have abnormal glucose tolerance were excluded from both the study and the control series.

Six weeks after delivery a $50-\mathrm{g}$ oral glucose tolerance test was carried out in all women who had had a large baby, and $\mathrm{HbA}_{1}$ measurement was repeated. Plasma glucose was measured by a glucose oxidase method using a Technicon autoanalyzer. The World Health Organisation (1965) criteria were used and a fasting or 2-hour concentration below $7.4 \mathrm{mmol} / 1(133 \mathrm{mg} / 100 \mathrm{ml})$ was considered to be normal.
\end{abstract}

\section{Results}

Nine of the women who had had large babies had an $\mathrm{HbA}_{1}$ concentration on the first or second day after delivery above the normal range for our laboratory. The mean concentration $( \pm S D)$ for the women who had had big babies was $7 \cdot 28 \pm 0 \cdot 8 \%$. All except one of the women who had had normal-sized babies had an $\mathrm{HbA}_{1}$ concentration

TABLE I-Hb $A_{1}$ concentrations (\%) in 50 mothers of big babies and 50 mothers of normal-sized babies (controls)

\begin{tabular}{lccccccccc}
\hline $\mathrm{HbA}_{1}$ concentrations & $5 \cdot 5-5.9$ & $6-6.4$ & $6.5-6.9$ & $7-7 \cdot 4$ & $7 \cdot 5-7.9$ & $8-8 \cdot 4$ & $8.5-8.9$ & $9-9 \cdot 4$ & $9 \cdot 5-9 \cdot 9$ \\
\hline $\begin{array}{l}\text { No of mothers: } \\
\text { With big babies } \\
\text { With normal-sized babies }\end{array}$ & 4 & 7 & 12 & 13 & 9 & 5 & 2 & 1 & 1 \\
\hline
\end{tabular}

TABLE II-Distribution of birthweight centiles

\begin{tabular}{|c|c|c|c|c|c|c|c|c|c|c|c|c|c|c|}
\hline Centile birthweight & $10-$ & $20-$ & $30-$ & $40-$ & $50-$ & $60-$ & 70 & $80-$ & $90-$ & 95- & $96-$ & 97- & $98-$ & $99-100$ \\
\hline $\begin{array}{l}\text { Big babies } \\
\text { Babies of controls } \\
\text { Babies of obese mothers }\end{array}$ & 2 & 2 & 6 & 9 & $\begin{array}{r}11 \\
1\end{array}$ & $\begin{array}{l}8 \\
1\end{array}$ & 7 & 5 & & $\begin{array}{r}13 \\
2\end{array}$ & 8 & $\begin{array}{l}6 \\
2\end{array}$ & $\begin{array}{r}12 \\
1\end{array}$ & $\begin{array}{r}11 \\
5\end{array}$ \\
\hline
\end{tabular}

The concentration of glycosylated haemoglobin $\left(\mathrm{HbA}_{1}\right)$, however, does give an indication of mean blood glucose concentrations over the preceding month. ${ }^{1}$ Hence this value, measured in the puerperium, might be expected to identify women who had high blood glucose concentrations before delivery.

Diabetic Department, Royal Infirmary, Edinburgh EH3 9YW

J M STEEL, MB, MRCPED, senior registrar

Simpson Memorial Maternity Pavilion, Edinburgh EH3 9EF P THOMSON, MB, MRCOG, senior registrar

University of Edinburgh, Edinburgh EH8 9YL

F JOHNSTONE, MD, MRCOG, senior lecturer, department of obstetrics A F SMITH, MD, FRCPATH, senior lecturer, department of clinical chemistry within the normal range, and the mean for this group was $6 \cdot 75 \pm 0.57 \%$. This gave $t=3.76$ with $\mathrm{p}<0.001$. From calculating the normal postpartum range on the basis of the control group the mean $\pm 2 S D$ was $5 \cdot 6-7 \cdot 9$, which was almost exactly the normal range we have obtained for adult non-diabetics. The distribution of the $\mathrm{HbA}_{1}$ results in the two groups is shown in table I. No woman in either group had a total haemoglobin concentration below $10 \mathrm{~g} / \mathrm{dl}$ at the time that the $\mathrm{HbA}_{1}$ was measured.

The centile distribution of both groups of babies is shown in table II. Since tables were not available for centile distributions above $95 \%$ we calculated the observed birthweight centiles above $95 \%$ assuming a normal distribution for infant birthweights. Although this assumption may be contested it does allow a comparative assessment of the weights of the different babies.

Two mothers in the control group and 10 in the big baby group were significantly obese-that is, more than $120 \%$ of the standard weight for their height at 20 weeks' gestation. One of the nine who had an abnormal $\mathrm{HbA}_{1}$ concentration was obese. Further details of these nine patients are shown in table III. 
TABLE III-Details of nine mothers with abnormal $H b A_{1}$ concentrations (\%)

\begin{tabular}{|c|c|c|c|c|c|}
\hline $\begin{array}{l}\text { Case } \\
\text { No }\end{array}$ & $\begin{array}{l}\text { HbA } \\
\text { 1st or } 2 \mathrm{nd} \text { day } \\
\text { after delivery }\end{array}$ & $\begin{array}{c}\mathrm{HbA}_{1} \\
6 \text { weeks } \\
\text { after delivery }\end{array}$ & $\begin{array}{l}\text { Baby's weight } \\
\text { at birth } \\
\text { (g) }\end{array}$ & Centile & Obesity \\
\hline $\begin{array}{l}1 \\
2 \\
3 \\
4 \\
5 \\
6 \\
7 \\
8 \\
9\end{array}$ & $\begin{array}{l}8 \cdot 0 \\
8 \cdot 1 \\
8 \cdot 1 \\
8 \cdot 2 \\
8 \cdot 2 \\
8 \cdot 8 \\
8.9 \\
9 \cdot 0 \\
9 \cdot 8\end{array}$ & $\begin{array}{l}7 \cdot 1 \\
6 \cdot 8 \\
6.9 \\
6 \cdot 6 \\
7 \cdot 1 \\
6 \cdot 3 \\
7 \cdot 4 \\
6.8\end{array}$ & $\begin{array}{l}4600 \\
4310 \\
4450 \\
4250 \\
4780 \\
4310 \\
4270 \\
4210 \\
4720\end{array}$ & $\begin{array}{l}99 \\
96 \\
98 \\
97 \\
99 \\
96 \\
98 \\
97 \\
99\end{array}$ & + \\
\hline
\end{tabular}

Three mothers, including one who had a high $\mathrm{HbA}_{1}$ concentration could not be traced after delivery; all the other mothers had normal glucose tolerance at six weeks after delivery and all $\mathrm{HbA}_{1}$ concentrations had returned to normal at that time.

\section{Discussion}

As expected there was a higher proportion of obese mothers among those with big babies than in the control group. ${ }^{4}$ There is a tendency for heavy babies to come from obese mothers or mothers with a high $\mathrm{HbA}_{1}$ concentration but there is no statistically significant association between the two and only one patient with a high $\mathrm{HbA}_{1}$ concentration was obese.

The nine women with high $\mathrm{HbA}_{1}$ concentrations immediately after delivery represent $18 \%$ of those with large babies. The risk of gestational diabetics having large babies is difficult to estimate because of variable criteria for diagnosis and because if detected gestational diabetes is normally treated. Opperman found that $40 \%$ of gestational diabetics had babies over the 90 th centile $^{5}$ when treated with diet but not insulin and O'Sullivan found $13 \%$ in a similar study. ${ }^{6}$ We can estimate the incidence of heavy babies in gestational diabetics if we assume that about $2.5 \%$ of unselected pregnant women have gestational diabetes and that about $4 \%$ of non-diabetics have babies weighing above the 95 th centile. The 50 big babies would then be made up of babies of $97.5 \%$ of the population who have a $4 \%$ risk and those of the $2.5 \%$ of the population with an $x \%$ risk. From our figures if 41 of our 50 mothers are non-diabetic and 9 are diabetic:

$$
x=\frac{97 \cdot 5}{2 \cdot 5} \times \frac{9}{41} \times 4=34 \% \text {. }
$$

This rough estimate of risk appears to be reasonable.

Without the evidence of glucose tolerance tests in late pregnancy we cannot confirm the diagnosis of gestational diabetes in the nine mothers with high postnatal concentrations of $\mathrm{HbA}_{1}$. Nevertheless, the overall correlation between overweight babies and a raised mean concentration of $\mathrm{HbA}_{\mathbf{1}}$ in their mothers suggests that glucose tolerance has been impaired in at least some of this group. It will be of interest to follow up these patients in their subsequent pregnancies and in the long term to see if they develop diabetes.

We thank Mrs Sarah Dickson and Mrs Margaret Oliver for secretarial help and Dr L Prescott for statistical advice.

\section{References}

${ }^{1}$ Fluckiger R, Berger W, Winterhalter KH. Haemoglobin A $\mathrm{A}_{1}$. Reliable index of diabetic control. Diabetologia 1977;13:393.

${ }^{2}$ Kynoch PAM, Lehmann $\mathrm{H}$. Rapid estimation of glycosylated $\mathrm{Hb}$ for routine purposes. Lancet 1977 ;ii:16.

${ }^{3}$ Fraser DM, Smith AF, Gray RS, et al. Glycosylated haemoglobin concentrations in newly diagnosed diabetics before and during treatment. Br Med F 1979;i:979-81.

4 Thomson AM, Billewicz WZ, Hytten FF. The assessment of fetal growth. fournal of Obstetrics and Gynaecology of the British Commonwealth 1968; $75: 903-16$.

5 Oppermann W, Gugliucci C, O'Sullivan MJ, Hanover B, CameriniDavalos RA. Gestational diabetes and macrosomia. In: CameriniDavalos RA, Cole HS, eds. Early diabetes in early life. London: Academic Press, 1975:455.

6 O'Sullivan JB, Gellis SS, Dandrow RV, Tenney BO. The potential diabetic and her treatment in pregnancy. Obstet Gynecol 1966;27:683-9.

(Accepted 10 March 1981)

\section{SHORT REPORTS}

\section{Seatone is ineffective in rheumatoid arthritis}

Seatone is an extract of the New Zealand green-lipped mussel Perna canaliculus. It has been found to have anti-inflammatory activity in an experimental model $^{1}$ and has been enthusiastically reported in newspapers. ${ }^{2}$ A controlled clinical trial has been reported, ${ }^{3}$ suggesting that the green-lipped mussel is effective in rheumatoid arthritis and osteoarthritis while having a low incidence of side effects. Our study was designed to test the anti-inflammatory efficacy of a single course of four weeks' treatment with Seatone.

\section{Patients, methods, and results}

Thirty outpatients with rheumatoid arthritis took part in a cross-over study to compare Seatone $300 \mathrm{mg}$ with an identical placebo capsule three times daily. The placebo capsule consisted of dried fish and had an offensive smell indistinguishable from that of Seatone. Each treatment was given for four weeks and was added to the patients' existing drug regimen. The order of treatment was randomised and balanced. The patients were receiving various analgesic and anti-inflammatory drugs but these had been constant for at least four weeks before the start of the study and remained constant during the study. All patients had arthritis that was inadequately controlled by existing treatment, and all had requested a trial course of Seatone in response to an advertisement in the waiting area of the clinic.

Note was made at the start of the study and at the end of each treatment period of the pain score, using a visual analogue scale, duration of morning stiffness, articular index, proximal interphalangeal joint circumference, and analgesic requirements. Preference for one or other treatment period was measured at the end of the study, when side effects were recorded. The results were analysed using Student's $t$ test applied to paired data, except for the duration of morning stiffness and preference, which were analysed using the Wilcoxon test.

Twenty-six patients completed the study. The table summarises the results. There were no significant differences between Seatone and placebo in any measurement. Ten patients preferred Seatone, nine preferred placebo, and seven had no preference.

All the patients had requested Seatone treatment, so it is not surprising that several responded well. Thirteen out of 22 patients $(59 \%)$ with morning stiffness at the start of the study noted a substantial reduction in its duration, and in two cases it disappeared completely. Figures for the placebo group were identical. One patient was so enthusiastic about the first period of treatment that she returned her stick to the physiotherapy department; she

Means of measurements made at start of study and at end of each treatmen period

\begin{tabular}{lccccc}
\hline & $\begin{array}{c}\text { Pain } \\
\text { score }\end{array}$ & $\begin{array}{c}\text { Duration of } \\
\text { morning } \\
\text { stiffness } \\
\text { (min) }\end{array}$ & $\begin{array}{c}\text { Articular } \\
\text { index }\end{array}$ & $\begin{array}{c}\text { Proximal } \\
\text { inter- } \\
\text { phalangeal } \\
\text { joint } \\
\text { size (mm) }\end{array}$ & $\begin{array}{c}\text { Analgesic } \\
\text { consumption } \\
\text { (number } \\
\text { of tablets) }\end{array}$ \\
\hline Initially & 12.3 & $43 \cdot 7$ & 11.5 & 567.7 & \\
After Seatone & 11.0 & 30.6 & $9 \cdot 0$ & 569.3 & 58.8 \\
After placebo & 11.5 & 34.2 & $9 \cdot 0$ & 568.8 & 66.5 \\
\hline
\end{tabular}

